\title{
INFORMACIJSKA ANKSIOZNOST STUDENATA FAKULTETA ZDRAVSTVENIH STUDIJA SVEUČILIŠTA U MOSTARU
}

\author{
Kristian Planinić ${ }^{1}$, Gabriela Mandić1, Josip Šimić ${ }^{1}$ \\ ${ }^{1}$ Fakultet zdravstvenih studija Sveučilišta u Mostaru, 8800 Mostar, Bosna i Hercegovina \\ Rad je primljen 20.09.2020.. Rad je recenziran 24.09.2020. Rad je prihvaćen 19.10.2020.
}

\section{SAŽETAK}

Uvod: Anksioznost je psihološko stanje koje je danas gotovo neizbježno zbog načina života ljudi. Informacijska anksioznost može se protumačiti kao strah i/ili bojazan od traženja informacijskih resursa tijekom postupka traženja informacija. Cilj: Ispitati razinu informacijske anksioznosti studenata na Fakultetu zdravstvenih studija Sveučilišta u Mostaru, te najvažnije izvore informacijske anksioznosti.

Ispitanici i metode: Provedeno je istraživanje na uzorku od 174 ispitanika, koristeći Upitnik anksioznosti pretraživanja informacija (ISAS). Istraživanje je provedeno u studenom 2019. godine na Fakultetu zdravstvenih studija Sveučilišta u Mostaru.

Rezultati: Od ukupnog broja anketiranih njih 96 \% ima određenu razinu informacijske anksioznosti (pretežito blagu razinu), dok samo $4 \%$ nema razvijenu informacijsku anksioznost. Razina informacijske anksioznosti različita je u odnosu na pojedinca pa tako imamo sedam pojedinaca bez informacijske anksioznosti, $15 \mathrm{~s}$ niskom informacijskom anksioznosti, 128 s blagom informacijskom anksioznosti, $22 \mathrm{~s}$ umjerenom informacijskom anksioznosti i 2 studenta s izraženom informacijskom anksioznosti.

Zaključak: Razina informacijske anksioznosti kod većine studenata je blago razvijena. Razlike između studijskih grupa i studijskih smjerova nisu statistički značajne, dok je jedina statistički značajna razlika između studijskih grupa kod tehničkih prepreka.

Ključne riječi: Informacijska anksioznost, traženje znanstvenih informacija, studenti Osoba za razmjenu informacija:

Kristian Planinić

E mail: kristian.planinic@fzs.sum.ba 


\section{UVOD}

Anksioznost je psihološko stanje koje je danas gotovo neizbježno zbog načina života ljudi, sastavni je dio života i u njemu ima adaptivnu funkciju, no ona postaje poremećaj onda kada je neprestano prisutna u životu pojedinca (1-3). Anksioznost je opći izraz za nekoliko poremećaja koji uzrokuju nervozu, strah i bojazan, definirana je kao afektivni osjećaj straha ili nelagodnosti uzrokovan bojazni ili iščekivanjem negativnih ishoda, a očituje se izbjegavajućim ponašanjem $(4,5)$. Suvremena informacijska okruženja korjenito mijenjaju procese učenja i istraživanja. Pripadnici akademske zajednice studiraju, istražuju i komuniciraju svoje rezultate $\mathrm{u}$ informacijskim okruženjima koja su se u posljednjem desetljeću stubokom promijenila (6-9). Sustavi za pretraživanje znanstvenih informacija podrazumijevaju sve akademske baze podataka koje sadrže znanstvene informacije za studente i koje se mogu pojavljivati u nekoliko oblika (10). Poznavanje vještina za pretraživanje ovih izvora je temelj oslobađanja od straha i nesigurnosti kada su u pitanju studenti i prikupljanje znanja (11). Kroz te procese pretraživanja javlja se informacijska anksioznost. Informacijska anksioznost može se protumačiti kao strah i/ili bojazan od traženja informacijskih resursa tijekom postupka traženja informacija (12). Anksioznost kod traženja informacija oduvijek se shvaćala kao temeljna psihološka barijera koja uzrokuje ne samo "različite kognitivne, emocionalne i bihevioralne efekte kod studenata”, već utječe i na njihov akademski učinak (13). Nesigurnost i anksioznost su primijećeni u radovima kao glavna uloga u različitim fazama postupka traženja informacija (14). Erfanmanesh i sur. proveli su istraživanje na raznim fakultetima na Sveučilištu u Kuala Lumpuru, Malezija na uzorku od 375 postdiplomanata i utvrdili kako 96,5 \% studenata ima određeni nivo informacijske anksioznosti (nizak, srednji, visok i veoma visok) dok samo 3,5 $\%$ njih nema informacijsku anksioznost (15). Među različitim demografskim čimbenicima otkriveno je da su spol, razina studija, dob i učestalost korištenjem knjižnice korelati informacijske anksioznosti. Suprotno tome nije pronađena povezanost između različitih podskupina informacijske anksioznosti i nacionalnosti, dobivenih instrukcija o vještinama informacijske pismenosti, studijskog smjera i učestalosti korištenjem Interneta (16). Naveed je proveo istraživanje u Pakistanu na uzorku od 31 studenta koristeći se metodom kritičnog incidenta. Intervjui licem u lice provedeni su za prikupljanje podataka posjetom sudionicima u njihovim odjelima. Rezultati su pokazali kako je informacijska anksioznost kod studenata veoma rasprostranjena, no u različitim oblastima, odnosno svaki student je imao različit stadij i različito viđenje problema (17). Naveed i Ameen proveli su studiju na uzorku od 251 postdiplomskih studenta na Sveučilištu u Punjabu, Lahore. Također je dokazana povezanost informacijske anksioznosti sa gore navedenim faktorima (18). Aghaei i sur. u svome istraživanju pokazali da zbog različitih radionica za obuku studenti ovog sveučilišta imaju nižu razinu informacijske anksioznosti od prosjeka u usporedbi s drugim istraživanjima (19). Cilj ovog istraživanja je utvrditi razinu informacijske anksioznosti studenata preddiplomskog i diplomskog studija na Fakultetu zdravstvenih studija Sveučilišta u Mostaru, te najvažnije izvore informacijske anksioznosti.

\section{ISPITANICI I METODE}

Istraživanje je provedeno na Fakultetu zdravstvenih studija Sveučilišta u Mostaru u studenom 2019. godine. U istraživanju su sudjelovala 183 ispitanika, podijeljenih u šest studijskih skupina. Sukladno kriterijima isključenja u istraživanje je uključeno 174 ispitanika. Svih 9 isključenih iz istraživanja odnosilo se na one koji nisu do kraja popunili anketne upitnike.

Za realizaciju postavljenog cilja i dobivanja odgovora na postavljene hipoteze koristio se anketni upitnik za određivanje informacijske anksioznosti pri traženju informacija Upitnik anksioznosti pretraživanja informacija (ISAS) razvijen od strane Erfanmanesh i sur. 2012 godine. Anketni upitnik sastavljen je od 47 pitanja, odnosno 47 Likretovih skala u rasponu od 1 do 5 , gdje je $1=$ u potpunosti se ne slažem, $2=$ ne slažem se, $3=$ neodlučan sam, $4=$ slažem se, $5=$ u potpunosti se slažem. Pitanja su podijeljena u 6 subskala koje se odnose na sljedeće: 
- prepreke povezane s izvorima informacija,

- prepreke povezane s računalom i Internetom,

- prepreke povezane s knjižnicom,

- prepreke povezane s pretraživanjem informacija,

- tehničke prepreke i

- prepreke povezane s identifikacijom teme (10).

Upitnik koji je rabljen u istraživanju prilagođen je za potrebe istraživanja, odnosno pitanje pod rednim brojem 24 koje u izvornom upitniku glasi: „Sveučilišna knjižnica ne nudi dovoljno informacijskih usluga za studente poslijediplomskih studija“, za ovo istraživanje prilagođeno je za studente preddiplomskih studija, odnosno za studente diplomskih studija.

Ispitanici su prije ispunjavanja anketnog upitnika bili upućeni u pojam informacijske anksioznosti, te $\mathrm{u}$ anonimnost upitnika i korištenje rezultata istraživanja isključivo u svrhe rada. Svi ispitanici dobrovoljno su pristali na popunjavanje upitnika.

Kriteriji uključenja: student na Fakultetu zdravstvenih studija, preddiplomski studij, diplomski studij. Kriteriji isključivanja: nepotpuni anketni upitnici, studenti koji ne studiraju na Fakulteta zdravstvenih studija Sveučilišta u Mostaru, studenti koji nisu završna godina preddiplomskog ili diplomskog studija.

\section{STATISTIČKA OBRADA PODATAKA}

Prikupljeni podatci statistički su obrađeni pomoću metoda deskriptivne statistike i prikazani u tabličnom obliku. Za analizu kategoričkih varijabli rabio se $\chi 2$ test. Dobivene statističke razlike prihvaćene su kao statistički značajne za $\mathrm{p}<0,05$. Za statistič$\mathrm{ku}$ analizu dobivenih podataka rabio se programski sustav SPSS for Windows (inačica 13.0, SPSS Inc, Chicago, Illinois, SAD).

\section{REZULTATI}

Tablica 1: Opis uzorka anketiranih ispitanika

\begin{tabular}{|c|c|c|c|c|}
\hline Studij & $\begin{array}{l}\text { Broj } \\
\text { ispi- } \\
\text { tanika }\end{array}$ & $\begin{array}{l}\text { Muški } \\
\text { spol }\end{array}$ & \begin{tabular}{|l} 
Ženski \\
spol
\end{tabular} & $\begin{array}{l}\text { Pros- } \\
\text { ječna } \\
\text { dob }\end{array}$ \\
\hline $\begin{array}{l}\text { Preddiplomski } \\
\text { sveučilišni studij } \\
\text { sestrinstva }\end{array}$ & 33 & 1 & 32 & $\begin{array}{l}21,15 \\
(19-27)\end{array}$ \\
\hline $\begin{array}{l}\text { Preddiplomski } \\
\text { sveučilišni studij } \\
\text { fizioterapije }\end{array}$ & 35 & 7 & 28 & $\begin{array}{l}21,03 \\
(20-23)\end{array}$ \\
\hline $\begin{array}{l}\text { Preddiplomski } \\
\text { sveučilišni studij ra- } \\
\text { diološke tehnologije }\end{array}$ & 35 & 12 & 23 & $\begin{array}{l}21,23 \\
(20-26)\end{array}$ \\
\hline $\begin{array}{l}\text { Diplomski } \\
\text { sveučilišni studij } \\
\text { kliničke zdravstvene } \\
\text { njege }\end{array}$ & 26 & 3 & 23 & $\begin{array}{l}26,62 \\
(22-45)\end{array}$ \\
\hline $\begin{array}{l}\text { Diplomski } \\
\text { sveučilišni studij } \\
\text { kliničke fizioterapije }\end{array}$ & 15 & 5 & 10 & $\begin{array}{l}23,67 \\
(22-29)\end{array}$ \\
\hline $\begin{array}{l}\text { Diplomski } \\
\text { sveučilišni studij ra- } \\
\text { diološke tehnologije }\end{array}$ & 30 & 14 & 16 & $\begin{array}{l}22,63 \\
(22-23)\end{array}$ \\
\hline UKUPNO: & 174 & 42 & 132 & $\begin{array}{l}22,72 \\
(19-45)\end{array}$ \\
\hline
\end{tabular}

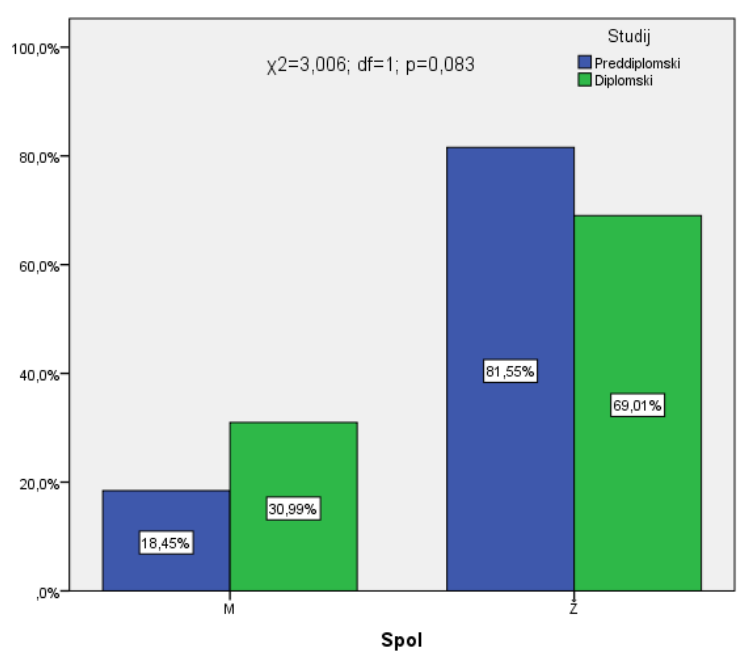

Slika 1. Spolna zastupljenost anketiranih ispitanika na studijskim skupinama

Nije bilo značajnih razlika u spolnoj zastupljenosti među skupinama preddiplomskog i diplomskog studija (slika 1). 
Planinić K, Mandić G, Šimić J. Informacijska anksioznost studenata Fakulteta zdravstvenih studija Sveučilišta u Mostaru. Zdravstveni glasnik. 2020;6(2):31-41.

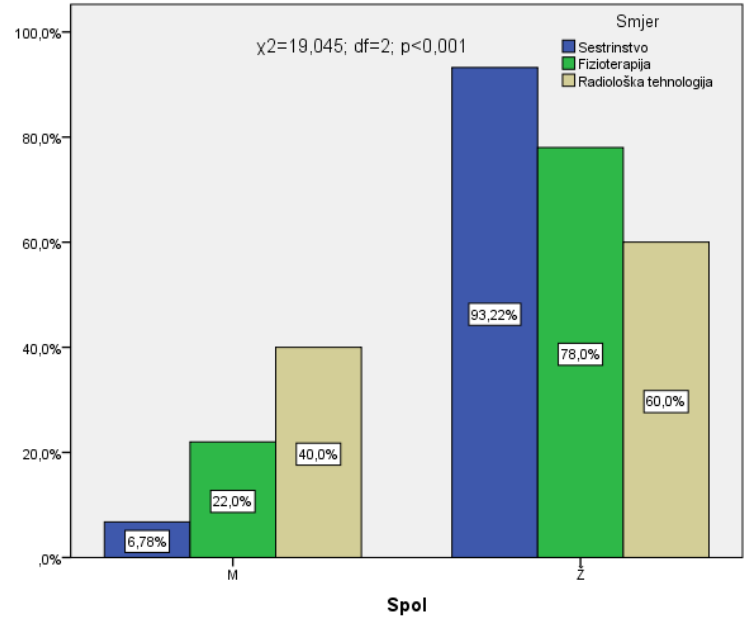

Slika 2. Spolna zastupljenost anketiranih ispitanika na studijskim smjerovima

Muškaraca je bilo najmanje na smjeru sestrinstva, a najviše na smjeru radiološke tehnologije, uočene razlike su bile statistički značajne (slika 2 ).

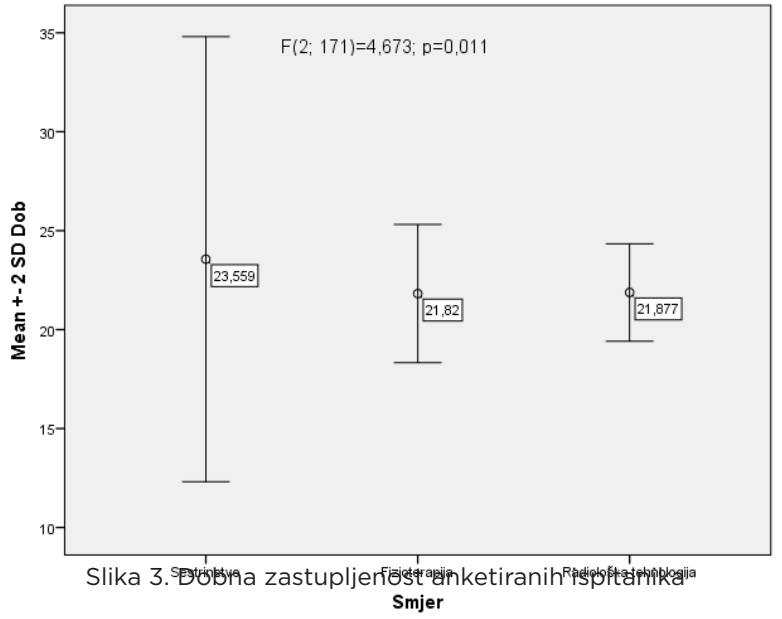

U odnosu na dob, studenti sestrinstva su bili značajno stariji od ostalih dviju skupina, između studenata fizioterapije i radiološke tehnologije nije bilo statistički značajnih razlika (slika 3 ).

Tablica 2. Razina informacijske anksioznosti prema studijskoj grupi

\begin{tabular}{|c|c|c|c|c|c|c|}
\hline & \multicolumn{4}{|c|}{ Studij } & \multirow{3}{*}{$\chi^{2}$} & \multirow{3}{*}{$\mathrm{p}$} \\
\hline & \multicolumn{2}{|c|}{ Preddiplomski } & \multicolumn{2}{|c|}{ Diplomski } & & \\
\hline & $\mathrm{n}$ & $\%$ & $\mathrm{n}$ & $\%$ & & \\
\hline Prepreke povezane s informacijskim izvorima & & & & & 7,081 & 0,069 \\
\hline Nema anksioznosti & 9 & 8,7 & 0 & 0,0 & & \\
\hline Niska anksioznost & 10 & 9,7 & 6 & 8,5 & & \\
\hline Blaga anksioznost & 64 & 62,1 & 52 & 73,2 & & \\
\hline Umjerena anksioznost & 20 & 19,4 & 13 & 18,3 & & \\
\hline Prepreke povezane s računalom i internetom & & & & & 7,275 & $0,112^{*}$ \\
\hline Nema anksioznosti & 4 & 3,9 & 1 & 1,4 & & \\
\hline Niska anksioznost & 7 & 6,8 & 10 & 14,1 & & \\
\hline Blaga anksioznost & 75 & 72,8 & 56 & 78,9 & & \\
\hline Umjerena anksioznost & 10 & 9,7 & 3 & 4,2 & & \\
\hline Izražena anksioznost & 7 & 6,8 & 1 & 1,4 & & \\
\hline Prepreke povezane s knjižnicom & & & & & 4,729 & $0,292^{*}$ \\
\hline Nema anksioznosti & 2 & 1,9 & 0 & 0,0 & & \\
\hline Niska anksioznost & 13 & 12,6 & 8 & 11,3 & & \\
\hline Blaga anksioznost & 65 & 63,1 & 53 & 74,6 & & \\
\hline Umjerena anksioznost & 19 & 18,4 & 10 & 14,1 & & \\
\hline Izražena anksioznost & 4 & 3,9 & 0 & 0,0 & & \\
\hline Prepreke povezane s pretraživanjem informacija & & & & & 4,663 & $0,310^{*}$ \\
\hline Nema anksioznosti & 1 & 1,0 & 1 & 1,4 & & \\
\hline
\end{tabular}


Planinić K, Mandić G, Šimić J. Informacijska anksioznost studenata Fakulteta zdravstvenih studija Sveučilišta u Mostaru. Zdravstveni glasnik. 2020;6(2):31-41.

\begin{tabular}{|c|c|c|c|c|c|c|}
\hline Niska anksioznost & 14 & 13,6 & 14 & 19,7 & & \\
\hline Blaga anksioznost & 76 & 73,8 & 46 & 64,8 & & \\
\hline Umjerena anksioznost & 7 & 6,8 & 9 & 12,7 & & \\
\hline Izražena anksioznost & 5 & 4,9 & 1 & 1,4 & & \\
\hline Tehničke prepreke & & & & & 13,446 & $0,005^{*}$ \\
\hline Nema anksioznosti & 8 & 7,8 & 0 & 0,0 & & \\
\hline Niska anksioznost & 9 & 8,7 & 14 & 19,7 & & \\
\hline Blaga anksioznost & 66 & 64,1 & 51 & 71,8 & & \\
\hline Umjerena anksioznost & 18 & 17,5 & 6 & 8,5 & & \\
\hline Izražena anksioznost & 2 & 1,9 & 0 & 0,0 & & \\
\hline Prepreke povezane s prepoznavanjem teme & & & & & 6,294 & $0,138^{*}$ \\
\hline Nema anksioznosti & 2 & 1,9 & 3 & 4,2 & & \\
\hline Niska anksioznost & 22 & 21,4 & 9 & 12,7 & & \\
\hline Blaga anksioznost & 60 & 58,3 & 52 & 73,2 & & \\
\hline Umjerena anksioznost & 18 & 17,5 & 7 & 9,9 & & \\
\hline Izražena anksioznost & 1 & 1,0 & 0 & 0,0 & & \\
\hline ISAS & & & & & 7,767 & $0,078^{*}$ \\
\hline Nema anksioznosti & 7 & 6,8 & 0 & 0,0 & & \\
\hline Niska anksioznost & 9 & 8,7 & 6 & 8,5 & & \\
\hline Blaga anksioznost & 70 & 68,0 & 58 & 81,7 & & \\
\hline Umjerena anksioznost & 15 & 14,6 & 7 & 9,9 & & \\
\hline Izražena anksioznost & 2 & 1,9 & 0 & 0,0 & & \\
\hline
\end{tabular}

Studenti preddiplomskih i diplomskih studija imaju određenu razinu informacijske anksioznosti. Gledajući ukupni skor ISAS upitnika vidljivo je da je informacijska anksioznost pretežito blago razvijena, studenti preddiplomskog studija 68 \%, dok je kod studenata diplomskog studija 81,7\%.

Tablica 3. Razina informacijske anksioznosti prema studijskom smjeru

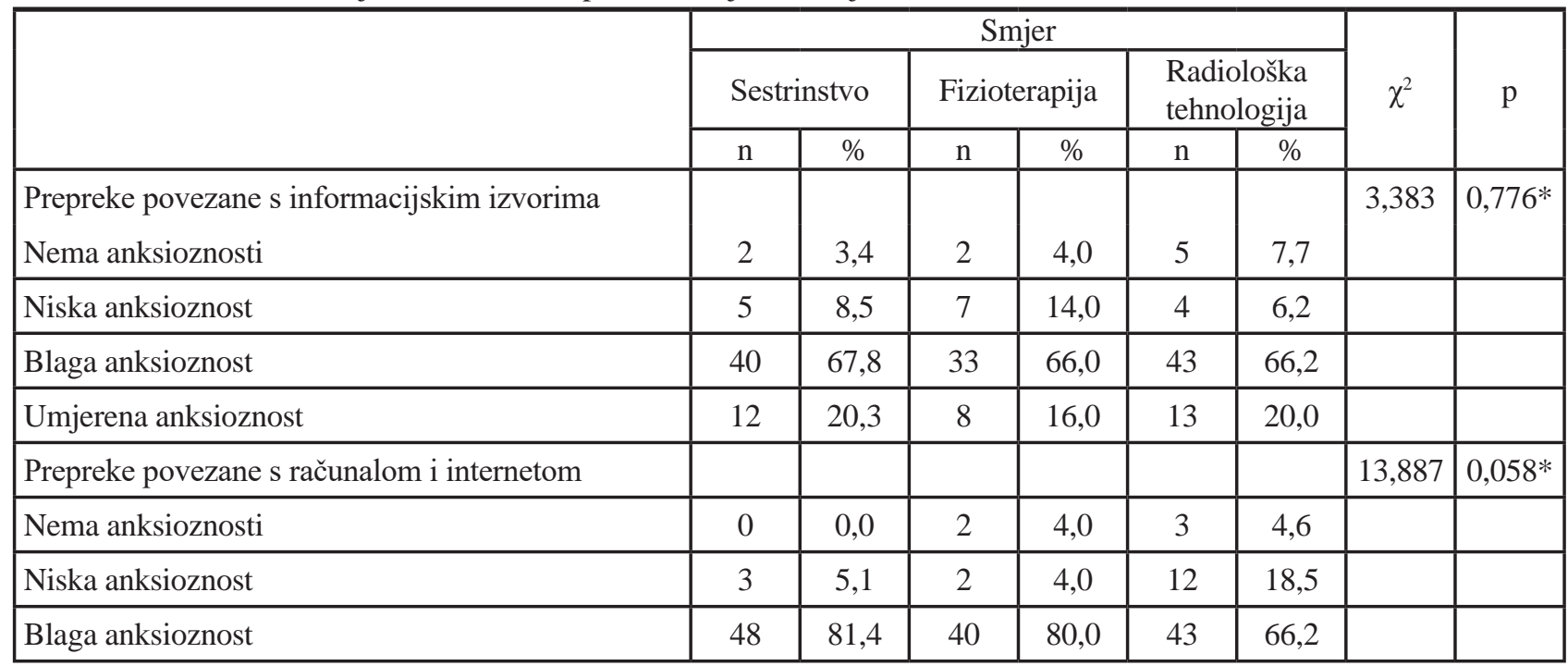


Planinić K, Mandić G, Šimić J. Informacijska anksioznost studenata Fakulteta zdravstvenih studija Sveučilišta u Mostaru. Zdravstveni glasnik. 2020;6(2):31-41.

\begin{tabular}{|c|c|c|c|c|c|c|c|c|}
\hline Umjerena anksioznost & 6 & 10,2 & 2 & 4,0 & 5 & 7,7 & & \\
\hline Izražena anksioznost & 2 & 3,4 & 4 & 8,0 & 2 & 3,1 & & \\
\hline Prepreke povezane s knjižnicom & & & & & & & 4,845 & $0,817 *$ \\
\hline Nema anksioznosti & 1 & 1,7 & 1 & 2,0 & 0 & 0,0 & & \\
\hline Niska anksioznost & 7 & 11,9 & 5 & 10,0 & 9 & 13,8 & & \\
\hline Blaga anksioznost & 39 & 66,1 & 36 & 72,0 & 43 & 66,2 & & \\
\hline Umjerena anksioznost & 9 & 15,3 & 8 & 16,0 & 12 & 18,5 & & \\
\hline Izražena anksioznost & 3 & 5,1 & 0 & 0,0 & 1 & 1,5 & & \\
\hline Prepreke povezane s pretraživanjem informacija & & & & & & & 8,596 & 0,324 \\
\hline Nema anksioznosti & 0 & 0,0 & 0 & 0,0 & 2 & 3,1 & & \\
\hline Niska anksioznost & 12 & 20,3 & 6 & 12,0 & 10 & 15,4 & & \\
\hline Blaga anksioznost & 40 & 67,8 & 37 & 74,0 & 45 & 69,2 & & \\
\hline Umjerena anksioznost & 4 & 6,8 & 4 & 8,0 & 8 & 12,3 & & \\
\hline Izražena anksioznost & 3 & 5,1 & 3 & 6,0 & 0 & 0,0 & & \\
\hline Tehničke prepreke & & & & & & & 9,307 & $0,265^{*}$ \\
\hline Nema anksioznosti & 1 & 1,7 & 3 & 6,0 & 4 & 6,2 & & \\
\hline Niska anksioznost & 10 & 16,9 & 6 & 12,0 & 7 & 10,8 & & \\
\hline Blaga anksioznost & 40 & 67,8 & 29 & 58,0 & 48 & 73,8 & & \\
\hline Umjerena anksioznost & 8 & 13,6 & 10 & 20,0 & 6 & 9,2 & & \\
\hline Izražena anksioznost & 0 & 0,0 & 2 & 4,0 & 0 & 0,0 & & \\
\hline Prepreke povezane s prepoznavanjem teme & & & & & & & 5,071 & $0,802 *$ \\
\hline Nema anksioznosti & 2 & 3,4 & 1 & 2,0 & 2 & 3,1 & & \\
\hline Niska anksioznost & 12 & 20,3 & 6 & 12,0 & 13 & 20,0 & & \\
\hline Blaga anksioznost & 37 & 62,7 & 33 & 66,0 & 42 & 64,6 & & \\
\hline Umjerena anksioznost & 8 & 13,6 & 10 & 20,0 & 7 & 10,8 & & \\
\hline Izražena anksioznost & 0 & 0,0 & 0 & 0,0 & 1 & 1,5 & & \\
\hline \multicolumn{9}{|l|}{ ISAS } \\
\hline Nema anksioznosti & 2 & 3,4 & 2 & 4,0 & 3 & 4,6 & & \\
\hline Niska anksioznost & 3 & 5,1 & 5 & 10,0 & 7 & 10,8 & & \\
\hline Blaga anksioznost & 46 & 78,0 & 36 & 72,0 & 46 & 70,8 & & \\
\hline Umjerena anksioznost & 7 & 11,9 & 6 & 12,0 & 9 & 13,8 & & \\
\hline Izražena anksioznost & 1 & 1,7 & 1 & 2,0 & 0 & 0,0 & & \\
\hline *Fisherov egzaktni test & & & & & & & & \\
\hline
\end{tabular}

Kao što je utvrđeno i u tablici 2, tako i ovdje možemo uočiti kako studenti imaju određenu razinu informacijske. Gledajući ukupni skor ISAS upitnika po određenom studijskom smjeru uočljivo je kako je razina informacijske anksioznosti pretežito blago razvijena (78 \% studij sestrinstva, $72 \%$ studij fizioterapije, 70,8 \% studij radiološke tehnologije). 
Planinić K, Mandić G, Šimić J. Informacijska anksioznost studenata Fakulteta zdravstvenih studija Sveučilišta u Mostaru. Zdravstveni glasnik. 2020;6(2):31-41.

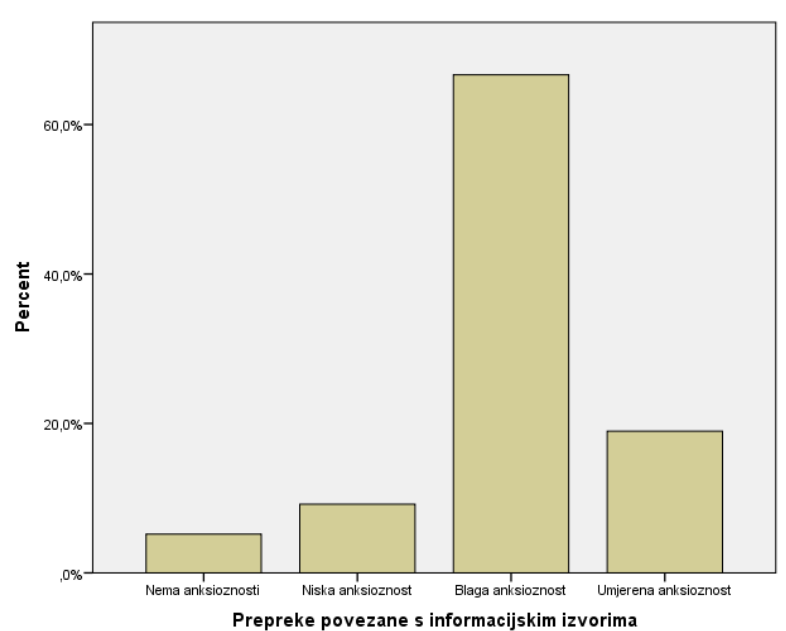

Slika 4. Ukupna razina informacijske anksioznosti kod prepreka povezanim s informacijskim izvorima

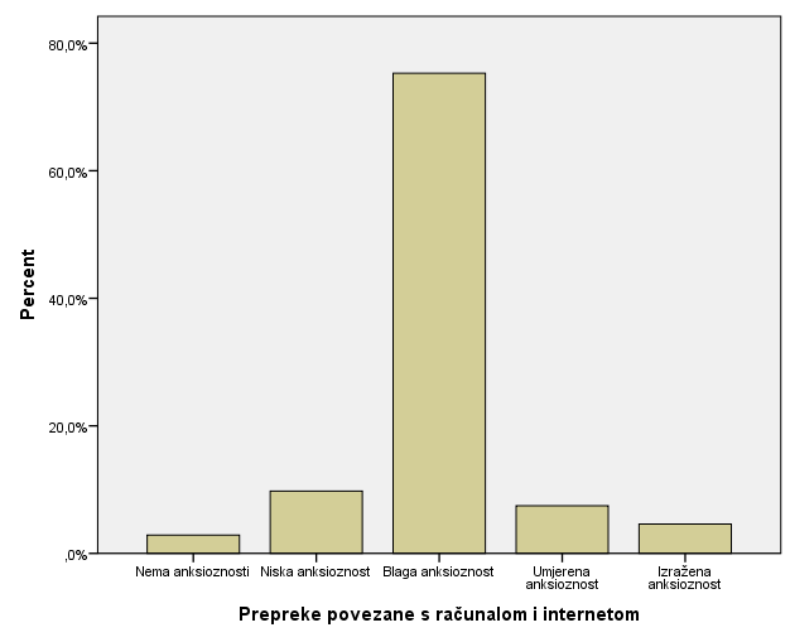

Slika 5. Ukupna razina informacijske anksioznosti kod prepreka povezanim s računalom i internetom

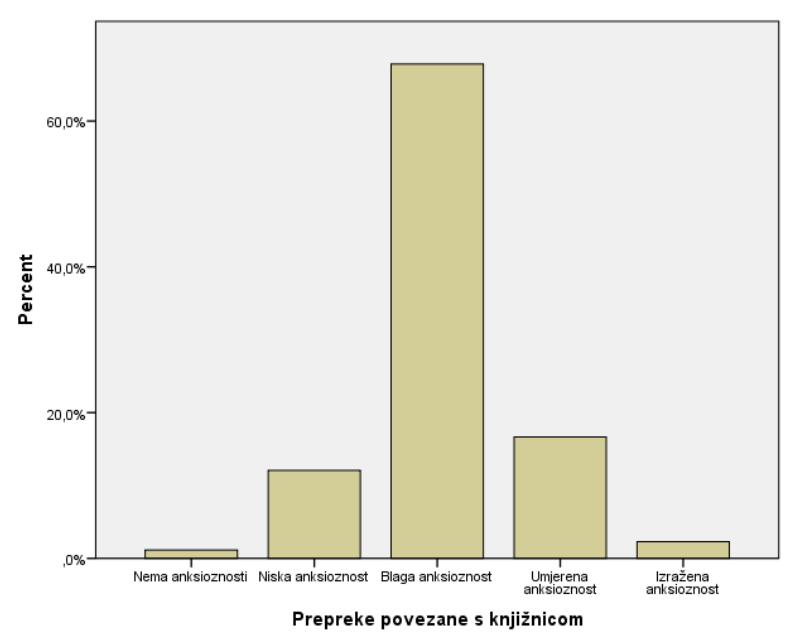

Slika 6. Ukupna razina informacijske anksioznosti kod prepreka povezanim s knjižnicom

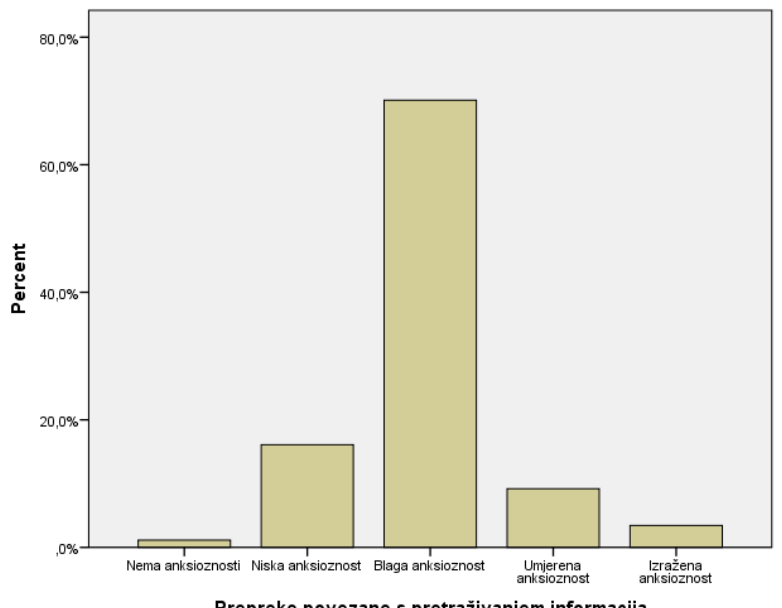

Prepreke povezane s pretraživanjem informacija

Slika 7. Ukupna razina informacijske anksioznosti kod prepreka povezanim s pretraživanjem informacija

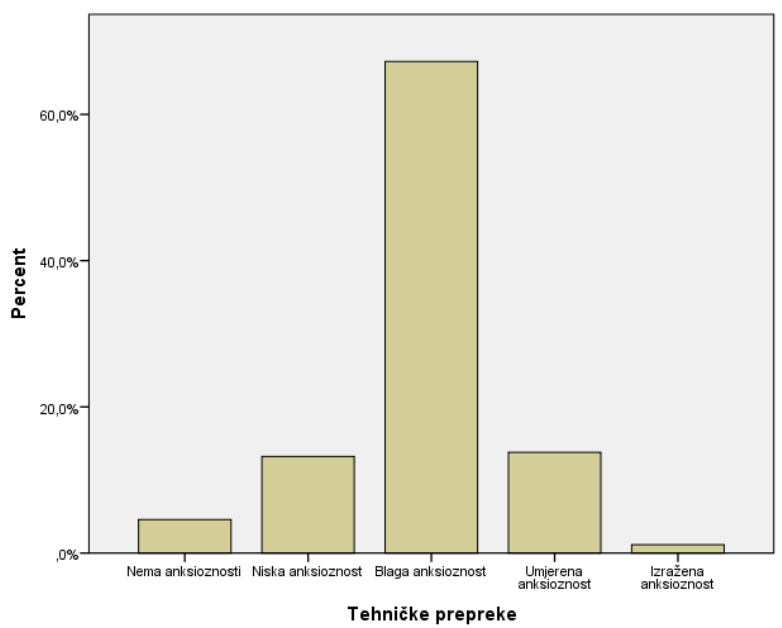

Slika 8. Ukupna razina informacijske anksioznosti kod tehničkih prepreka

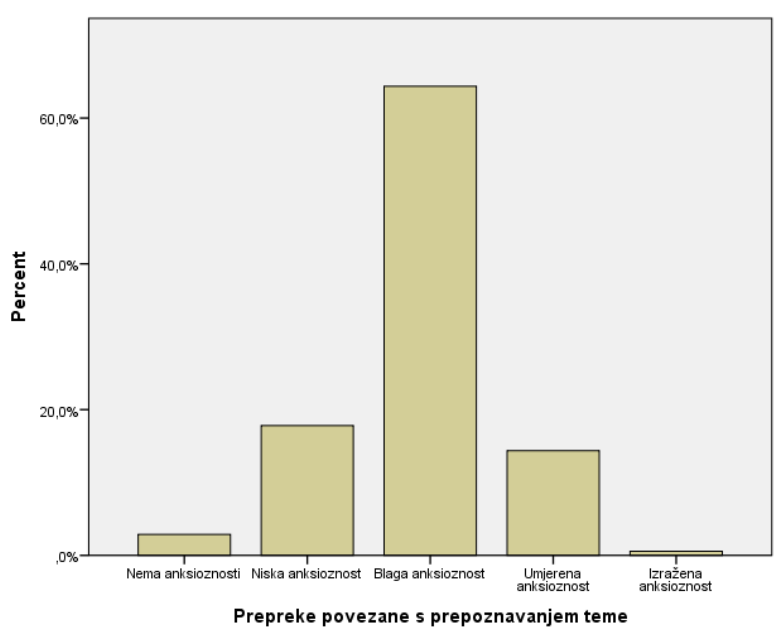

Slika 9. Ukupna razina informacijske anksioznosti kod prepreka povezanim s prepoznavanjem teme 


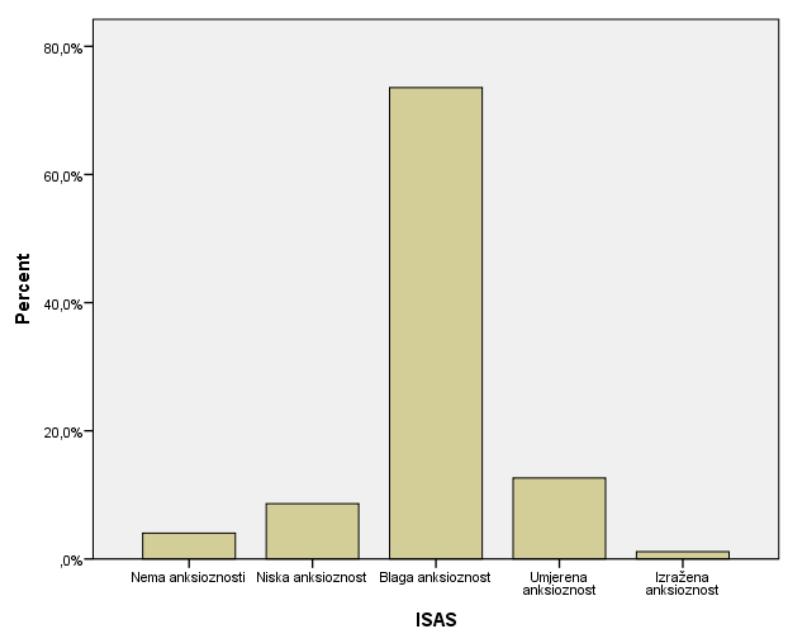

Slika 10. Ukupna razina informacijske anksioznosti

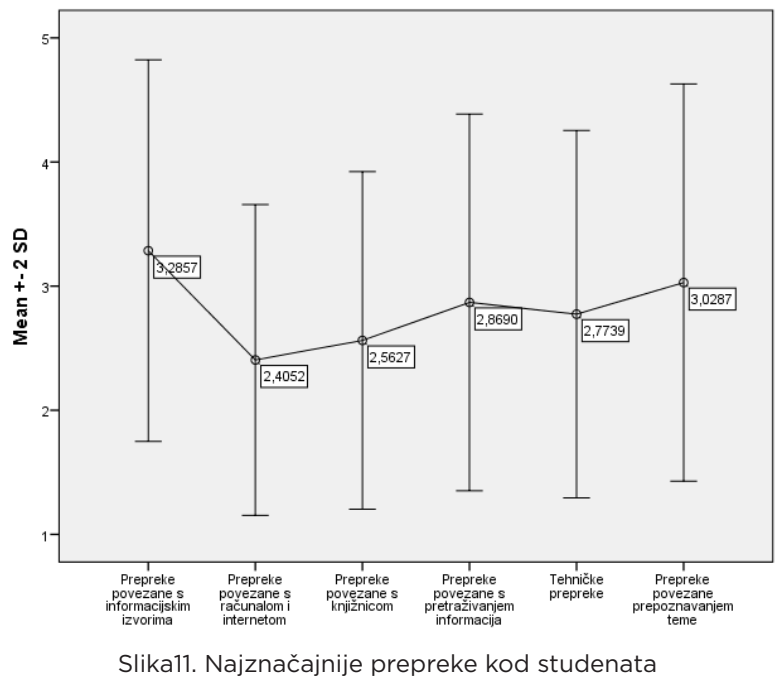

\section{RASPRAVA}

Analizom rezultata ovog istraživanja dobili smo uvid $\mathrm{u}$ postojanost $\mathrm{i}$ razinu informacijske anksioznosti kod studenata zdravstvenih usmjerenja. Prva hipoteza (Studenti Fakulteta zdravstvenih studija Sveučilišta u Mostaru imaju određenu razinu informacijske anksioznosti (nisku, blagu, umjerenu, izraženu)) je potvrđena. Druga hipoteza (Studenti preddiplomskih studija imaju višu razinu informacijske anksioznosti u odnosu na studente diplomskih studija) je djelomično potvrđena. Očekivano je kako će ukupna razina informacijske anksioznosti kod studenata preddiplomskog studija biti viša u odnosu na studente diplomskih studija, no statistički značajnu razliku možemo primijetiti kod određenih prepreka. Ukupan broj ispitanika bio je 183. Sukladno već ustanovljenim kriterijima isključenja u istraživanje je uključeno 174 ispitanika. Svih 9 isključenih iz istraživanja odnosilo se na one koji nisu do kraja popunili anketne upitnike. Nije bilo statistički značajnih razlika u spolnoj zastupljenosti među skupinama preddiplomskog i diplomskog studija. Kada je u pitanju spolna zastupljenost na studijskim smjerovima vidimo kako je muškaraca najmanje na smjeru sestrinstva $(6,78$ $\%)$, a najviše na smjeru radiološke tehnologije (40 $\%)$, uočene razlike bile su statistički značajne. Dob anketiranih ispitanika jeste u rasponu od 19 godina do 45 godina. Studenti sestrinstva bili su značajno stariji od ostalih dviju skupina, između studenata fizioterapije i radiološke tehnologije nije bilo statistički značajnih razlika.

Autor ISAS upitnika koristio je razine za knjižničnu anksioznost i ukupne razmjere ranije definirane od strane Anwar, Al-Kandari i Al-Qallaf (2004.) kao korisnu metodu za određivanje razine anksioznosti u različitim pod-dimenzijama pri traženju informacija. Navedeni autori predlažu pet razina knjižnične anksioznosti; bez anksioznosti, niska anksioznost, blaga anksioznost, umjerena anksioznost i izražena anksioznost. Svaki pojedinac može biti okarakteriziran kao blago anksiozan ako je kompozicija njegovih informacije unutar jednog standardnog odstupanja od prosjeka ili $\mathrm{M} \pm \mathrm{SD}$. Osoba može imati nisku anksioznost ako je njen rezultat izvan jednog standardnog odstupanja s lijeve strane srednje vrijednosti, ali unutar dva standardna odstupanja od lijeve srednje vrijednosti, ili između M - SD i M - 2SD. Međutim, ako je anksioznost unutar $\mathrm{M}+\mathrm{SD}$ i $\mathrm{M}+2 \mathrm{SD}$, pojedinac ima umjerenu razinu anksioznosti. Pojedinac nema anksioznost ukoliko je rezultat ispod $\mathrm{M}$ - 2SD, ali anksioznosti je teška ukoliko je rezultat iznad $M+2 S D$. Razina anksioznosti pri traženju informacija je određena pomoću navedene metode za svaku od šest dimenzija kao i za ukupne razmjere.(15)

Uzevši u obzir upute za određivanje informacijske anksioznosti prema autoru ISAS upitnika možemo zaključiti sljedeće, da razvijenu informacijsku anksioznost ima $96 \%$ studenata, dok samo $4 \%$, odnosno 7 ispitanika nema. Uzevši u obzir rezultate 
iz drugih relevantnih istraživanja možemo reći kako smo postigli slične rezultate, međutim ta istraživanja su bila povezana za postdiplomske studije (15-19). Kada je u pitanju razina informacijske anksioznosti i razlika među preddiplomskim i diplomskom studijskim skupinama možemo uvidjeti kako je statistički značajna razlika kod tehničkih prepreka, dok u drugim domenama ISAS upitnika nismo imali statistički značajnih razlika. Kada je u pitanju razina informacijske anksioznosti kod studenata preddiplomskog studija možemo uvidjeti kako njih $7(6,8$ \%) nema informacijske anksioznosti, 9(8,7 \%) studenata ima nisku razinu informacijske anksioznosti, 70(68 \%) studenata ima blagu razinu informacijske anksioznosti, 15(14,6\%) ima umjerenu razinu informacijske anksioznosti, dok 2(1,9\%) studenta imaju izraženu (veoma visoku) informacijsku anksioznost. Kada su u pitanju studenti diplomskih studijskih skupina možemo uvidjeti kako nema studenata koji su bez nekog stupnja informacijske anksioznosti, također nijedan student nema izraženu informacijsku anksioznost (veoma visoku), dok njih 6(8,5 \%) ima nisku razinu informacijske anksioznosti, 58(81,7 \%) studenata ima blago razvijenu informacijsku anksioznost te 7(9,9\%) studenata ima umjerenu razinu informacijske anksioznosti. Ukupna razina informacijske anksioznosti pretežito je blago razvijena. Uzevši u obzir razinu informacijske anksioznosti i glavne prepreke kod studijskih smjerova možemo uvidjeti kako nema statistički značajnih razlika, dok je razina informacijske anksioznosti podjednako razvijena.

Razlike u razini informacijske anksioznosti mogu se uočiti na razini pojedinca, tj. svaki ispitanik kao individua ima različite stavove prema određenim preprekama koje su ključne za informacijsku anksioznost. Vidimo određene oscilacije u razvijenosti informacijske anksioznosti pa tako određeni pojedinci nemaju razvijenu informacijsku anksioznost, dok pojedinci imaju izraženu informacijsku anksioznost.

Nedostatci ovoga istraživanja mogu se tražiti u možda nedovoljnom broju ispitanika, te se predlaže u slijedećim istraživanjima na ovu temu dodatno proširiti populaciju koja obuhvaća studente zdravstvenih usmjerenja. Također, korisno bi bilo utvrditi koliko neki vid edukacije o informacijskog pismenosti i pretraživanju izvora znanstvenih informacija može pomoći u smanjenju nivoa informacijske anksioznosti. Neka istraživanja sugeriraju važnost obrazovanja informacijske pismenosti u okviru formalnog obrazovanja $(20,21)$, što smatramo vrlo važnim u procesu podizanja razine informacijske pismenosti.

Zaključno, rezultati ovoga istraživanja sugeriraju kako bi se implementacijom u nastavni sadržaj, koji podrazumijeva pretraživanje, korištenje i vrednovanje znanstvenih informacija u području biomedicine i zdravstva, moglo preventivno djelovati na pojavu informacijske anksioznosti kod studenata.

\section{ZAKLJUČAK}

Od ukupnog broja anketiranih ispitanika gotovo svi imaju određenu razinu informacijske anksioznosti, odnosno 96 \% studenata ima određenu razinu informacijske anksioznosti, dok samo $4 \%$, odnosno 7 ispitanika nema. Razlika u razini informacijske anksioznosti kod studenata preddiplomskih studija i studenata diplomskih studija nije statistički značajna. Kada je u pitanju razina informacijske anksioznosti u povezanosti s određenim preprekama, statistički značajne razlike pokazale su se kod tehničkih prepreka, gdje studenti preddiplomskog studija imaju višu razinu informacijske anksioznosti. Nema statistički značajnih razlika između studijskog smjera i razine informacijske anksioznosti. Prepreke povezane s informacijskim izvorima pokazale su se kao najznačajnije prepreke kod informacijske anksioznosti.

\section{LITERATURA}

1. Brajković M, Pavlović M, Babić D. Samopoštovanje, kvaliteta života i psihički simptomi studenata Fakulteta zdravstvenih studija Sveučilišta u Mostaru. Zdravstveni glasnik. 2017;2:13-19.

2. Galić K, Dodaj A, Ćorluka-Čerkez V, Lasic V, Pejić R, Šimić J, Vukojević M. Study of depression and anxiety in patients with asthma and chronic obstructive pulmonary disease Medicina Academica Mostariensia, 2018;(6)1- 
2:112-117. http://www.psychiatria-danubina. com/UserDocsImages/pdf/dnb_vol31_noSuppl\%201/dnb_vol31_noSuppl\%201_112.pdf

3. Hrkać I, Pavlović M, Haxhibeqiri S, Babić R, Martinac M, Babić D, Usporedba anksioznosti i depresivnosti u onkoloških pacijenata liječenih kemoterapijom i zračenjem. Zdravstveni glasnik. 2019;5(1):40-47.

4. Van Kampen DJ.: Library anxiety, the information search process and doctoral use of the library. PhD thesis. Florida: Univerity of Central Florida, 2003.

5. Ljubić O, Babić D. Anksioznost studenata Fakulteta zdravstvenih studija u Mostaru prije i nakon ispita. Zdravstveni glasnik. 2017;1:36-44.

6. Šimić J, Špiranec S. Informacijska pismenost. Mostar: Sveučilište u Mostaru. 2015.

7. Tepšić M, Šimić J, Čotić K, Čupić M. Važnost istraživanja i prakse utemeljene na dokazima za sigurnost bolesnika i kvalitetu zdravstvene njege. Zdravstveni glasnik. 2019;5(2):95-101. Pristupljeno na https://hrcak.srce.hr/228918 (20.09.2020.)

8. Šimić J, Tomić V, Vukojević M. Lokalna znanstvena infrastruktura u kontekstu zaštite od pandemije COVID-19. Zdravstveni glasnik. 2020;6(1):19-24. Pristupljeno na: https://hrcak. srce.hr/239140 (20.09.2020.).

9. Lasić Lazić J, Špiranec S, Banek Zorica M. Izgubljeni u novim obrazovnim okruženjima pronađeni $\mathrm{u}$ informacijskom opismenjivanju Medij. Istraž. 2012;18(1):125-142.

10. Šimić J, Babić D. Znanstvena komunikacija u biomedicini i zdravstvu. Zdravstveni glasnik. 2018;2:68-70. Pristupljeno sa: https://fzs. sum.ba/sites/default/files/Glasnik\%202-2018. pdf\#page $=70$ (19.09.2020.)

11. Blundell, S, Lambert F. Information Anxiety from the Undergraduate Student Perspective: A Pilot Study of Second-semester Freshmen. Journal of Education for Library and Information Science. 2014;55(4):261-273.

12. Erfanmanesh M. Information Seeking Anxiety: Effects of Gender, Level of Study and Age. Library Philosophy and Practice (e-journal) 2016. dostupno na: https://ijism.ricest.ac.ir/index. php/ijism/article/view/283/211

13. Erfanmanesh M, Abrizah A, Karim NHA. Development and Validation of the Information Seeking Anxiety Scale. Malaysian Journal of Library \& Information Science. 2012; 17(1): 2139.

14. Wilson ML, Wilson M. Social anxieties and collaborative information seeking. Collaborative Information Seeking Workshop at GROUP 2010; Sanibel Island, FL USA.

15. Erfanmanesh M, Abrizah A, Karim NHA. Information Seeking Anxiety: Concept, Measurement and Preliminary Research. International Journal of Information Science and Management. 2014; 12(1): 47-64.

16. Erfanmanesh M, Abrizah A, Karim NHA. The prevalence and correlates of information seeking anxiety in postgraduate students. $\mathrm{Ma}$ laysian Journal of Library \& Information Science. 2014 ; 19(2): 69-82.

17. Naveed MA. Exploring Information Seeking Anxiety among Research Students in Pakistan. LIBRI. 2016; 66(1): 73-82.

18. Naveed MA, Ameen K. Determining the Prevalence and Correlates of Information Seeking Anxiety Among Postgraduates in Pakistan. LIBRI. 2016; 67(3): 205-14.

19. Aghaei F, Soleymani MR, Rizi HA. Information seeking anxiety among M.A. Students of Isfahan University of Medical Sciences. J Educ Health Promot. 2017; 19; 6:14

20. Bailey, E. Constance Mellon demonstrated that college freshmen are afraid of academic libraries. Evidence Based Library and Information Practice, 2008;3(3):94-97. http://dx.doi. org/10.18438/B8FS60

21. Bell JC. Student affect regarding library-based and web-based research before and after an information literacy course. Journal of Librarianship and Information Science, 2011;43(2):120130. https://doi.org/10.1177/0961000610383634 


\title{
INFORMATION SEEKING ANXIETY OF STUDENTS OF FACULTY OF HEALTH STUDIES UNIVERSITY OF MOSTAR
}

Kristian Planinić ${ }^{1}$, Gabriela Mandić ${ }^{1}$, Josip Šimić ${ }^{1}$

${ }^{1}$ Faculty of Health Studies University of Mostar, 8800 Mostar, Bosnia and Herzegovina

\begin{abstract}
Introduction: Anxiety is a psychological condition almost inevitable due to the present way of life. Information seeking anxiety can be interpreted as the fear and/or apprehension of searching for information resources during the information seeking process.

Objective: Investigate the level of information seeking anxiety of students at the Faculty of Health Studies of the University of Mostar and examine the most relevant sources of information seeking anxiety.

Subjects and methods: The study was conducted on a sample of 174 subjects. Data were collected with the Information Seeking Anxiety Scale (ISAS). The study was conducted in November 2019 at the Faculty of Health Studies, University of Mostar.

Results: Out of the total number of subjects, $96 \%$ have some level of information seeking anxiety (mostly mild), while only $4 \%$ have not developed information seeking anxiety. The level of information anxiety is different in relation to the individual, therefore we have 7 individuals without any form of information seeking anxiety, 15 with low information seeking anxiety, 128 with mild information seeking anxiety, 22 with moderate information seeking anxiety, and 2 students with severe information seeking anxiety.

Conclusion: Most students have experienced a mild level of information seeking anxiety. Differences between study groups and study courses are not statistically significant, the only statistically significant difference was between study groups and technological barriers.
\end{abstract}

Key words: information seeking anxiety, information seeking, students

Correspondence:

Kristian Planinić

E-mail: kristian.planinic@fzs.sum.ba 